\title{
The cytotoxicity and apoptotic effects of verbascoside on breast cancer 4T1 cell line
}

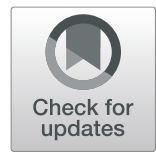

\author{
Atena Daneshforouz ${ }^{1}$, Samad Nazemi ${ }^{2}$, Omid Gholami ${ }^{2}$, Marzieh Kafami ${ }^{3,4^{*}}$ and Bahareh Amin ${ }^{2^{*}}$
}

\begin{abstract}
Background: Despite significant advancements in breast cancer therapy, novel drugs with lower side effects are still being demanded. In this regard, we investigated the anti-cancer features of verbascoside in 4T1 mouse mammary tumor cell.

Methods: First, MTT assay was performed with various concentrations (ranging between 5 to $200 \mu \mathrm{M}$ ) of verbascoside and IC50 was calculated. Then the expression of Bax, BCl-2, and caspase-3 was evaluated in treated 4 $\mathrm{T} 1$ cells. In addition, we investigated the expression of TLR4, MyD88, and NF-KB to ascertain the underlying mechanism of the anti-proliferative feature of verbascoside. Also, flow cytometry followed by double $\mathrm{PI}$ and Annexin $\vee$ was conducted to confirm the apoptosis-inducing effect of verbascoside.

Results: Our results from MTT assay showed verbascoside inhibits proliferation of 4 T1 cancer cells (IC50 $117 \mu \mathrm{M})$ while is safe for normal HEK293T cells. By qRT-PCR, we observed that verbascoside treatment $(100,117$ and, $130 \mu \mathrm{M})$ increases the expression of caspase-3 and Bax while reduces the expression of BCl-2. Also, verbascoside (100, 117 and, $130 \mu \mathrm{M}$ ) increased the expression of TLR4 only at $130 \mu \mathrm{M}$ dose and the expression of MyD88 whereas reduced the expression of NF-KB at mRNA level. Flow cytometry analysis also confirmed verbascoside induces apoptosis in 4 $\mathrm{T} 1$ cells at $117 \mu \mathrm{M}$.

Conclusion: Taken together, our data showed verbascoside is a safe natural compound for normal cells while has apoptosis-inducing feature through TLR4 axis on 4 T1 cells.
\end{abstract}

Keywords: Verbascoside, Breast cancer, Apoptosis, Toll like receptor, MyD88, NF-kB, Caspase-3

\section{Introduction}

Breast cancer is the major form of malignancy and the most fatal type of cancer in women around the world, with an increasing rate of prevalence and mortality [1]. Attainments in breast cancer treatment have provided various therapeutic options including radiotherapy, surgery, and chemotherapy. Chemotherapeutics are mainly nonselective and cause toxicity for healthy organs and

\footnotetext{
* Correspondence: kafami.m@gmail.com; amin.bahareh@gmail.com

${ }^{3}$ Cellular and Molecular Research Center, Sabzevar University of Medical

Sciences, Sabzevar, Iran

${ }^{2}$ Cellular and Molecular Research Center, Department of Physiology and Pharmacology, Faculty of Medicine, Sabzevar University of Medical Sciences, Sabzevar, Iran

Full list of author information is available at the end of the article
}

normal tissues which consequently lead to cardiac diseases, reproductive system disorders, neuropathy and infection [2]. Signaling pathways play a vital role during the development and progression of diseases, especially in cancer [3], therefore understanding involved mechanisms and therefore identifying novel drugs for treatment is an important goal in cancer research. In this regard, herbal plants with therapeutic effects have become an interesting field of study for cancer researchers [4]. Herbal medicines have shown promising insights as adjuvant therapy and even main treatment drug [5]. To date, the anti-proliferative effect of polyphenols, flavonoids, terpenoids has been reported in breast cancer treatment [6].

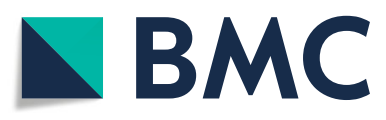

(c) The Author(s). 2021 Open Access This article is licensed under a Creative Commons Attribution 4.0 International License, which permits use, sharing, adaptation, distribution and reproduction in any medium or format, as long as you give appropriate credit to the original author(s) and the source, provide a link to the Creative Commons licence, and indicate if changes were made. The images or other third party material in this article are included in the article's Creative Commons licence, unless indicated otherwise in a credit line to the material. If material is not included in the article's Creative Commons licence and your intended use is not permitted by statutory regulation or exceeds the permitted use, you will need to obtain permission directly from the copyright holder. To view a copy of this licence, visit http://creativecommons.org/licenses/by/4.0/ The Creative Commons Public Domain Dedication waiver (http://creativecommons.org/publicdomain/zero/1.0/) applies to the data made available in this article, unless otherwise stated in a credit line to the data. 
Verbascoside is an active ingredient extracted from Cistanches Herba of Orobanchaceae family [7]. To date, antinociceptive, antioxidant, anti-inflammatory, as well as protection against Parkinson and Alzheimer's disease for this component have been reported [7, 8]. This phenolic substance by activating homeodomaininteracting protein kinase (HIPK)-p53 axis is able to reduce the proliferation of colorectal cancer cells and initiates apoptosis [9]. HIPK pathway modulates apoptosis by phosphorylating Ser46 activates $p 53$, which in turn leads to apoptosis phenomena by regulating $\mathrm{Bcl}-2$ associated $\mathrm{X}$ protein $(\mathrm{Bax})$. In addition, $p 53$ by suppressing nuclear factor kappa-light-chain-enhancer of activated $\mathrm{B}$ cells $(N F-\kappa B)$ pathway induces apoptosis. The p53 activated by HIPK can directly activate caspase to initiate apoptosis [10].

Toll-like receptor 4 (TLR4) is an important signaling pathway in inflammation which also plays a role in cancer prevention [11]. Downregulation of TLR4 is associated with increased tumor formation and metastasis in animal models [12]. TLR4 activation can boost immune system defense against tumor cells through $M y D 88$ which leads to activation or maturation of immune cells such as dendritic cells (DCs), macrophages and T cells [11]. Based on this evidence, to date, various therapeutic drugs for activating TLR4 in cancer treatment has been implemented [13, 14].

Cancer research has shown that caspase-3 mechanism has a strong link with cell death in tumors which has made it a preferred target for cancer treatment [15]. Change in the harmony of B-cell lymphoma $2(\mathrm{Bcl}-2)$ and $\mathrm{BCl}-2$-associated $\mathrm{X}$ protein $(\mathrm{Bax})$ ratio is responsible for the activation of Caspase-3 in response to death signals [16]. $\mathrm{Bcl}-2$ inhibits the activity of $\mathrm{Bax}$ which is located at the membrane of mitochondria. Bax initiates apoptosis by increasing permeability of mitochondria membrane which in turn disrupts its membrane and release of cytochrome $\mathrm{C}$ [17]. Increased $\mathrm{Bax} / \mathrm{Bcl}-2$ ratio reflects the condition of increased pro-apoptotic $B a x$ to an anti-apoptotic molecule of $\mathrm{Bcl}-2$ in cancer cells [18].

In the present study, we aimed to investigate the effect of verbascoside on breast cancer cell line $4 T 1$.

\section{Material and methods}

The mouse breast cancer cell lines designated as $4 T 1$ and human embryonic kidney cell lines designated as HEK293T were obtained from the Pasture Institute in Tehran,Iran.

\section{Cell culture and drug preparation}

$4 T 1$ and HEK293T cells were cultured in Dulbecco's Modified Eagle Medium (DMEM) and Roswell Park Memorial Institute 1640 (RPMI 1640) respectively, supplemented with $10 \%$ FBS (KalaZist CO) and 1\% Penicillin
(100 units $/ \mathrm{ml}) /$ Streptomycin $(100 \mu \mathrm{g} / \mathrm{ml})$. Flasks were incubated at $37^{\circ} \mathrm{C}$ in $\mathrm{CO}_{2}$ incubator with a $95 \%$ humidity. Media was changed every 2 days and at $85 \%$ confluency cells were passaged. After the third passage, cells were seeded in proper plates and number for further experiments [19].

The stock solution was made by dissolving $2 \mathrm{mg}$ of verbascoside powder in $100 \mu \mathrm{l} D M S O$ (stock A). Then $50 \mu \mathrm{l}$ of stock A was added to $950 \mu \mathrm{l}$ of media to make stock B (corresponding to the type of cells). Treatment concentrations were made from stock $B$, for instance, $5 \mu \mathrm{l}$ stock B was added to $995 \mu \mathrm{l}$ media to make $5 \mu \mathrm{M}$ concentration and likewise for the higher concentrations. Since the solvent we used was $D M S O$, we also considered a DMSO 10\% control in 3-[4,5-dimethylthiazole-2-yl]-2,5diphenyltetrazolium bromide (MTT) experiments.

\section{MTT assay}

In order to assess the response of cells to verbascoside at different concentrations and its toxicity, we performed MTT assay for both cell lines. $1 \times 10^{5}$ cells per well were seeded into 96 wells flat-bottom plates and incubated to grow for $24 \mathrm{~h}$. Then media was replaced with drugcontaining media with a defined concentration of verbascoside ranging between $5 \mu \mathrm{M}$ to $200 \mu \mathrm{M}$, and then cells were incubated for $24 \mathrm{~h}$. After removal of media, $M T T$ solution $(5 \mathrm{mg} / \mathrm{ml}$ in $P B S)$ was added to each well and plates were incubated for $4 \mathrm{~h}$. After that, $D M S O$ was used to dissolve formazan crystals in wells and absorbance was read at $570 \mathrm{~nm}(620 \mathrm{~nm}$ as the reference wavelength), by an enzyme-linked immunosorbent assay (ELISA) reader instrument. Then, half-maximal inhibitory concentration (IC50(was calculated via GraphPad Prism $^{\circ}$ [20], and was used for downstream experiments. The experiment was performed in triplicate.

\section{Gene expression analysis}

To perform reverse transcription polymerase chain reaction (RT-PCR), 4 T1 cells were seeded at $3.5 \times 10^{5}$ density in 6-well plates and allowed to grow overnight in the incubator. Next, cells were treated with different concentrations $(100,117$ and $130 \mu \mathrm{m})$ and incubated for another $24 \mathrm{~h}$. Afterward, RNA extraction from cells was performed via RNX-Plus (Sinaclon, Iran) according to manufacturer protocol. Quality and quantity of RNA samples were checked by Agarose Gel and Nanodrop BIO INTELLECTICA Nano100 (Canada). cDNA synthesis was carried out via RR037Q - Takara (Japan) according to the protocol provided by the manufacturer and with an equal starting nanogram of RNA fro each sample. Real-time PCR was performed by CFX96 Touch $^{\text {Tu }}$ Bio-Rad (USA) and using SYBR Green ${ }^{\circ}$ Yekta Tajhiz Azma. The sequence of primers used in this research is 
reported in Table 1. Relative expression fold changes were calculated through $2^{-\Delta \Delta C T}$ method [21].

\section{Flow cytometry analysis}

Apoptotic cells were detected using propidium iodide $(P I)$ and Annexin staining followed by flow cytometry. For this purpose, $4 T 1$ cells were seeded at $5 \times 10^{5}$ density in wells of 6-well plates and allowed to grow for $24 \mathrm{~h}$. Then media was removed and replaced with media containing $117 \mu \mathrm{M}$ verbascoside and plates were incubated for another $24 \mathrm{~h}$ again. After that time, cells were detached by Trypsin, and staining for Annexin and PI was performed by the protocol described elsewhere [22].

\section{Statistical analysis}

To analyze results from a statistical perspective, we used one-way analysis of variance (ANOVA) and Tukey posttest. All data are expressed as the mean \pm SD. $P$ values under 0.05 were considered statistically significant.

\section{Results}

Verbascoside inhibits the growth of $4 \mathrm{~T} 1$ cells but not HEK293T cells

$4 T 1$ and HEK293T cells were treated with different concentrations of verbascoside ( 5 to $200 \mu \mathrm{M}$ ), for $24 \mathrm{~h}$. MTT assay showed that verbascoside did not affect the viability of HEK293T cells, as normal control (Fig. 1-a). On the other hand, verbascoside effectively reduced the viability of $4 T 1$ cells in a dose-dependent manner (Fig. 1b). IC50 was calculated $116.7(\sim 117) \mu \mathrm{M}$ for verbascoside on $4 T 1$ cells and was used for further experiments (Fig. 1-c).
Verbascoside modulates gene expression of the apoptotic pathway

qRT-PCR analysis of treated $4 T 1$ cells demonstrated that verbascoside is able to initiate apoptosis via altering the expression pattern of related genes at the mRNA level. Verbascoside increased the expression of caspase-3 in a dose-dependent manner (Fig. 2-a). The expression of $B a x$ was increased by verbascoside $(100 \mu \mathrm{M} P<0.01$, $117 \mu \mathrm{M}, 130 \mu \mathrm{M} P<0.001)$ while the expression of $B c l-2$ was reduced $(P<0.001)$ (Fig. 2-b and $-\mathrm{c})$. In addition, the $\mathrm{Bax} / \mathrm{Bcl}-2$ ratio was increased dose-dependently by verbascoside (Fig. 2-d).

\section{Verbascosides alters the expression of MyD88, NF-KB and, TLR4}

To determine verbascoside by which pathway initiate apoptosis in $4 T 1$ cells, we also investigated the expression of TLR4, MyD88, and NF- $K B$ under treatment at the mRNA level. Verbascoside slightly increased the expression of TLR4 at mRNA level but it was not significant at $100 \mu \mathrm{M}$ and $117 \mu \mathrm{M}$ doses, however, the change was significant at the dose of $130 \mu \mathrm{M}(P<0.05)$ (Fig. 3a).

Also, verbascoside effectively increased the expression of $M y D 88$ gene in a dose-dependent manner at all three doses. The expression change was slightly significant at $100 \mu \mathrm{M}$ dose $(P<0.05)$ but was more significant at 117 and $130 \mu \mathrm{M}$ doses (for both $P<0.001$ ) (Fig. 3-b).

$N F-\kappa B$ gene expression was down-regulated by verbascoside dose dependently which was significant at $117 \mu \mathrm{M}(P<0.01)$ and $130 \mu \mathrm{M}$ concentration $(P<0.001)$ (Fig. 3-c).

Table 1 Summary of PCR primer pairs

\begin{tabular}{|c|c|c|}
\hline Name & Sequence of primers & Annealing Temperature \\
\hline \multirow[t]{2}{*}{$B a x$} & Forward: 5'CAAGGCCCTGTGCACTAAAGT3' & $60^{\circ} \mathrm{C}$ \\
\hline & Reverse: 5'AAGTAGGAGAGGAGGCCTTCC3' & \\
\hline \multirow[t]{2}{*}{$B C 12$} & Forward: 5'GGAGAAATCAAACAGAGGTCGC3' & $60^{\circ} \mathrm{C}$ \\
\hline & Reverse: 5'CGTCAACAGGGAGATGTCACC3' & \\
\hline \multirow[t]{2}{*}{ MyD88 } & Forward: 5'CTCCAGGTGTCCAACAGAAGC3' & $60^{\circ} \mathrm{C}$ \\
\hline & Reverse: 5'TCATCTTCCCCTCTGCCCTAG3' & \\
\hline \multirow[t]{2}{*}{$N F-K B$} & Forward: 5'GCCATTGAAGTGATCCAGGCA3' & $60^{\circ} \mathrm{C}$ \\
\hline & Reverse: 5TCCCGGAGTTCATCTATGTGCT3' & \\
\hline \multirow[t]{2}{*}{ TLR4 } & Forward 5'GCATGGATCAGAAAACTCAGC -5' & $60^{\circ} \mathrm{C}$ \\
\hline & Reverse: 5'TGTTTCAATTTCACACCTGGA -5' & \\
\hline \multirow[t]{2}{*}{ Caspase 3} & Forward: 5'GGAGCAGCTITGTGTGTGTG3' & $60^{\circ} \mathrm{C}$ \\
\hline & Reverse: 5'TCCAGGAATAGTAACCAGGTGC3' & \\
\hline \multirow[t]{2}{*}{ GAPDH } & Forward: 5'GGAAGGTGAAGGTCGGAGTCA3' & $60^{\circ} \mathrm{C}$ \\
\hline & Reverse: 5'GTCATTGATGGCAACAATATCCACT3' & \\
\hline
\end{tabular}






\section{Flow cytometry demonstrated apoptosis induction by verbascoside}

To ascertain the apoptotic effect of verbascoside on $4 T 1$ cells, we also performed $P I$ and Annexin- $V$ doublestaining followed by flow cytometry. $4 T 1$ cells were treated with verbascoside $(117 \mu \mathrm{M})$ for $24 \mathrm{~h}$ and then stained and flow cytometry was conducted. Results showed that verbascoside slightly increased the number of apoptotic cells compared to untreated. However, the percentage of necrosed cells were slightly higher in treated cells compared to untreated cells. Figure 4 shows the rate of apoptotic cells in verbascosid group comparison to the control group. Verbascoside increased the number of apoptotic cells by $0.64 \pm 0.6 \%$ compared to the control group $(0.22 \pm .0 .04)$ which shows was significant $(P<0.01)$.

\section{Discussion}

Since now, various biological functions of polyphenol compounds have been reported such as anti-oxidant, anti-inflammatory [23], and more importantly antitumor [24] activity. Verbascoside also belongs to this class of compounds and is an active phytochemical of Cistanches Herba of Orobanchaceae family. Some reports have shown this compound has anti-tumor and apoptosis-inducing features on glioblastoma [25], colorectal [26] and, head and neck carcinomas [27].

Our findings showed verbascoside has anti-tumor activity against breast cancer cells by initiating apoptosis cascade followed by activating $M y D 88$ pathway and reducing $N F-\kappa B$ at mRNA level with no toxic effect on normal cells. Our results from gene expression analysis and also flow cytometry revealed that verbascoside 

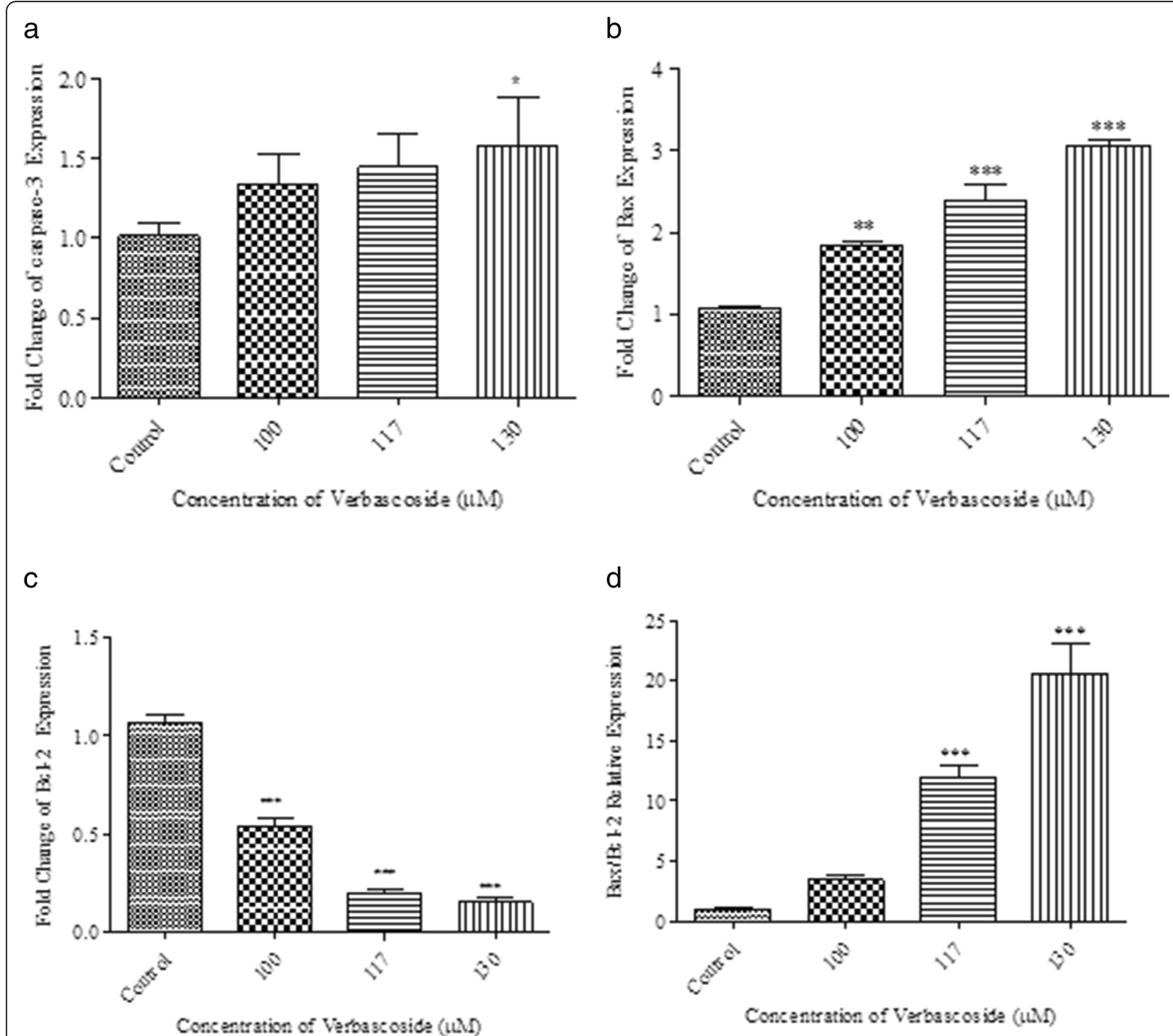

Fig. 2 Effect of verbascoside on the expression of genes related to apoptosis in $4 \mathrm{~T} 1$ cells. a Verbascoside treatment led to the overexpression of caspase3 but was only significant at $130 \mu \mathrm{M}$ dose. $\mathbf{b}$ Verbascoside in a dose-dependent manner significantly increased the expression of Bax gene at $100 \mu \mathrm{M}, 117 \mathrm{Mm}$ and, $130 \mu \mathrm{M}$. c Verbascoside significantly reduced the expression of Bcl-2 at $100 \mathrm{Mm}, 117 \mu \mathrm{M}$ and,. $\mathbf{d}$ The effect of verbascoside on the Bax/Bcl-2 ratio. At $100 \mu \mathrm{M}$ dose ratio $(N=3) .{ }^{* * *} P<0.001,{ }^{* *} P<0.01,{ }^{*} P<0.05$ compared to control

initiates apoptosis in breast cancer cells.. Also, we found that verbascoside at $130 \mu \mathrm{M}$ concentration is able to enhance the expression of TLR4.

Anti-cancer feature of verbascoside against various cancers has been reported [25, 27]. As MTT assay results showed that verbascoside is toxic to $4 T 1$ cells, we investigated the underlying mechanism. In this study, we measured the expression of genes related to apoptosis cascade in 4T1 cells. We showed verbascoside dosedependently increased the $\mathrm{Bax} / \mathrm{Bcl}-2$ ratio as a sign of apoptosis. Also, we showed overexpression of caspase-3 upon verbascoside treatment in $4 \mathrm{T1}$ cells. $\mathrm{Bax}$ and $\mathrm{Bcl}-2$ are major determiners of cell survival or apoptosis. $B c l-2$ is a member of the $B c l 2$ family of genes which confers survival to cancer cells $[28,29]$ whereas $\operatorname{Bax}$ is responsible for apoptosis initiation and eventually cell death [29]. Bax inhibits the activity of Bcl-2 upon binding and forming a heterodimer with, consequent of apoptosis stimuli [29]. In this condition, Bax by binding to mitochondrial membrane disrupts its integrity which in turn results in cytochrome $\mathrm{C}$ release into the cytoplasm. Cytochrome $\mathrm{C}$ by forming apoptosome with procaspase9 and apoptotic protease activating factor 1 , cleaves caspase- 3 and initiates apoptosis [30].

Our results of $P I$ and annexin- $V$ staining also confirmed apoptosis initiation by verbascoside. DNA 



C

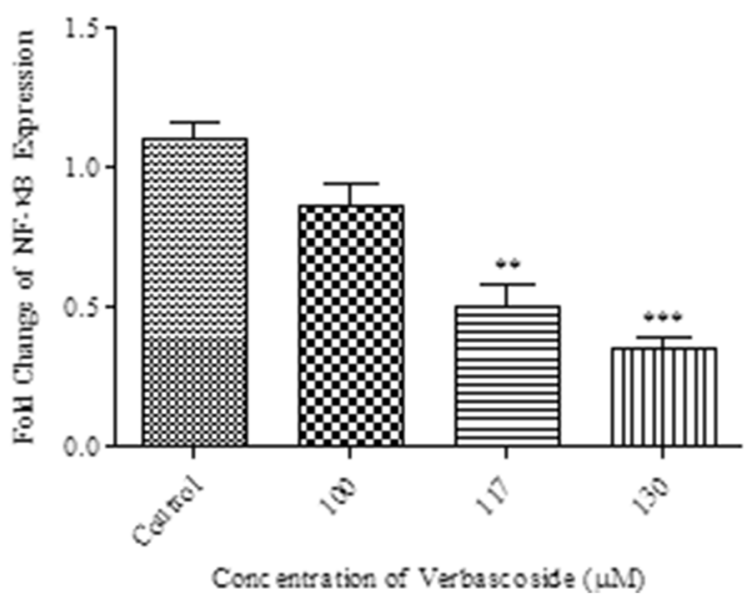

Fig. 3 Gene expression alteration of Nf-KB, MyD88 and, TLR4 by verbascoside in 4 T1 cells. a Shows verbascoside treatment led to overexpression of TLR4 but was only significant at $130 \mu \mathrm{M}$ dose $(P<0.05) ; 1.78 \pm 0.32$ fold. $\mathbf{b}$ Demonstrates verbascoside effectively increased the expression of MyD88 in a dose-dependent manner; $1.44 \pm 0.20$ fold at $100 \mu \mathrm{M}(P<0.05), 2.29 \pm 0.17$ at $117 \mu \mathrm{M}(P<0.001)$ and, $2.79 \pm 0.07$ at $130 \mu \mathrm{M}$ dose $(P<$ 0.001). $\mathbf{c}$ Exhibits the effect of verbascoside treatment on the expression of NF-KB in $4 \mathrm{~T} 1$ cells, verbascoside significantly reduced the expression of NF-KB by $0.50 \pm 0.13$ fold at $117 \mu \mathrm{M}(P<0.01)$ and $0.35 \pm 0.05$ fold at $130 \mu \mathrm{M}$ concentration $(P<0.001) .(N=3){ }^{* * *} P<0.001$, ** $P<0.01$, * $P<$ 0.05 compared to control

fragmentation subsequent of apoptosis is detectable by $P I$ staining due to to the ability of $P I$ in binding to DNA molecules. In addition, annexin- $V$ binds to phosphatidylserine $(P S)$ on the surface of cells [31]. Increase in the content of PS on the cell surface is a well-documented indicator of apoptosis in cells. Taken together, increased fluorescence in cells stained with $P I$ and annexin $V$ reflects apoptosis condition [32].

Myeloid differentiation primary response 88 (MyD88) pathway is able to mediate apoptosis which is a downstream molecule of TLR4 [33]. Inhibition of $N F-\kappa B$ after MyD88 activation induces apoptosis in cancer cells [34].
Our findings showed MyD88 and TLR4 were overexpressed by verbascoside. It seems that verbascoside by increasing the TLR4 at the cell surface acts on MyD88, as its downstreatm molecule, [35] and induces apoptosis by this mechanism. In addition, we observed $N F-\kappa B$ is downregulated which may be due to the activation of $M y D 88$ [34], or may be the direct effect of verbascoside [36]. Verbascoside has been reported to prevent $I_{\kappa} B \alpha$ degradation which keeps $N F-\kappa B$ in its inactive state in the cytoplasm of cells [27, 37]. Therefore, $M y D 88$ upon activation by upper regulatory signals initiates apoptosis pathway through FAS-associated death domain protein 


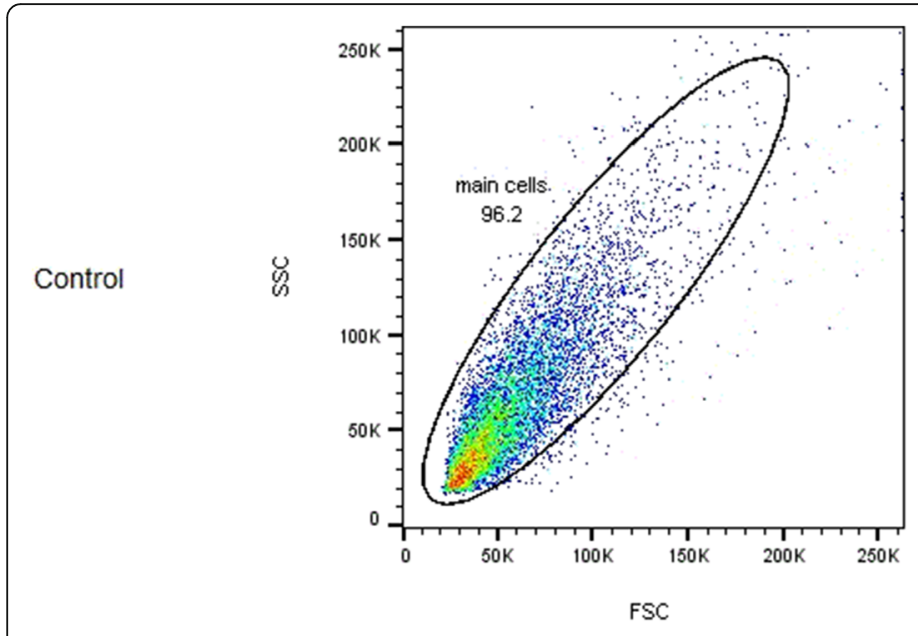

Unstain cells

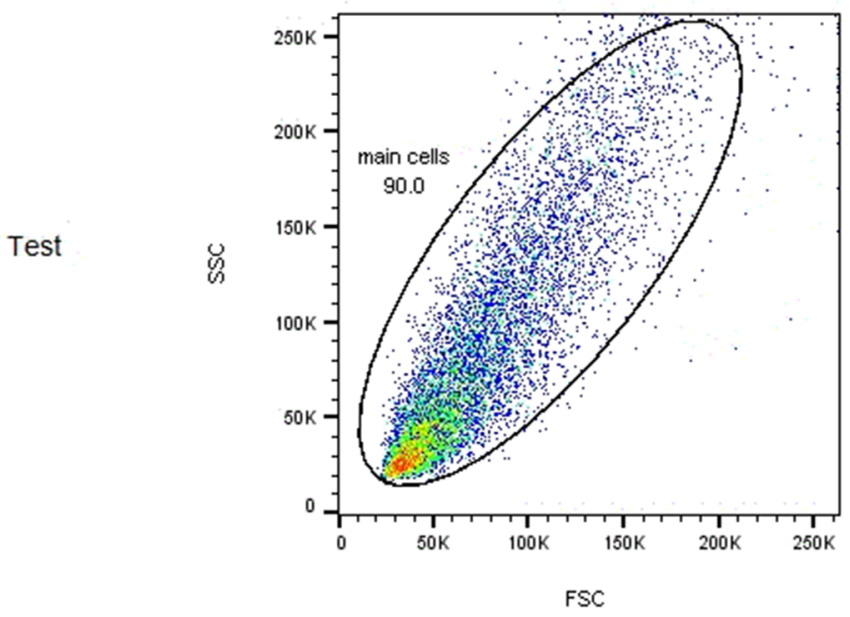

Unstain cells



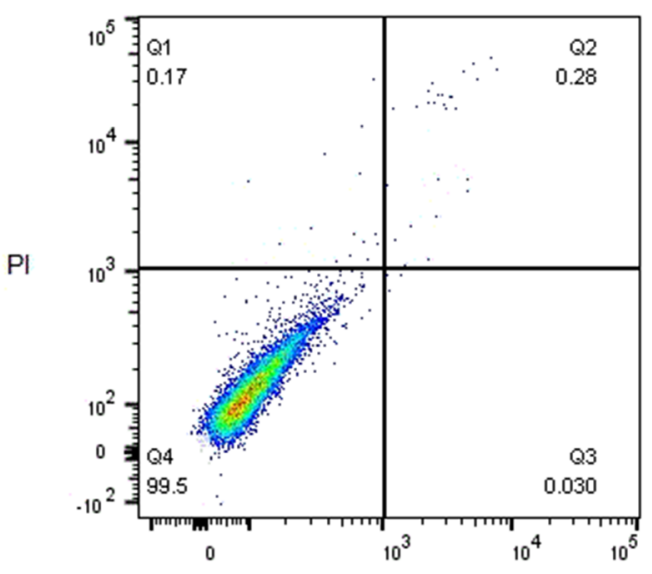

Anexin-FIC

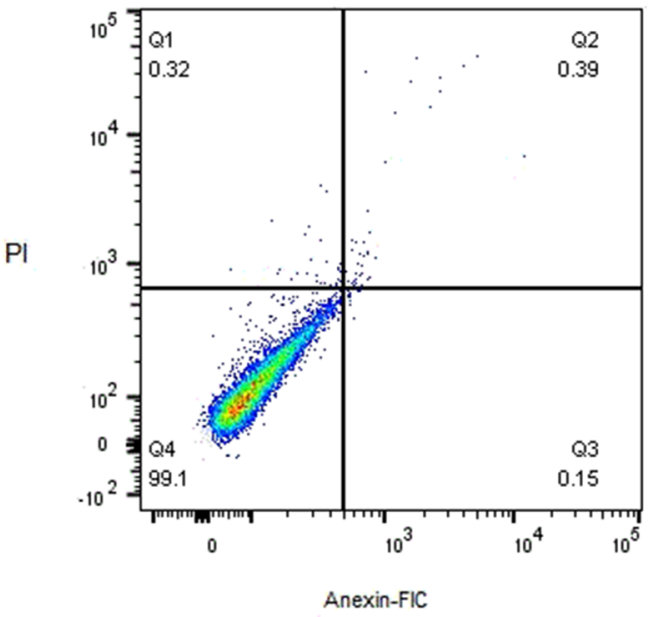

Fig. 4 Flow cytometry examination showed that verbascoside induces apoptosis in $4 \mathrm{~T} 1$ cells $(P<0.01 \mathrm{~N}=3)$. Control boxes refer to cells with no verbascoside treatment. Test boxes are showing cells under verbascoside treatment. Column graphs are showing the percentage of apoptotic cells. ${ }^{*} P<0.01, * P<0.05$ compared to control

$(F A D D)$ which consequently affects procaspase-8 and apoptosis cascade [38]. Verbascoside can activate HIPK2 [9] which in turn directly inhibits $N F-\kappa B$ to promote apoptosis [10].
In conclusion, herein, we showed that while verbascoside is safe and nontoxic for normal cells could be a a natural anti-tumor compound against breast cancer cells. 


\section{Acknowledgements}

The authors thank Cellular and Molecular Research Center, Department of Physiology and Pharmacology, Faculty of Medicine, Sabzevar University of Medical Sciences, Sabzevar, Iran.

\section{Authors' contributions}

M Kafami and B Amin designed the study, M Kafami analysis data and wright the manuscript. A Daneshforus, collected data and contributed to the interpretations of the data. S Nazemi and O Gholami contributed to the interpretations of the data. All authors have read and given final approval of the latest version of the manuscript.

\section{Funding}

This work was supported by the Vice Chancelor of Research, Sabzevar University of Medical sciences, Sabzevar, Iran.

\section{Availability of data and materials}

The data that support the findings of this study are available on request from the corresponding author. The data are not publicly available due to privacy or ethical restrictions.

\section{Declarations}

\section{Ethical approval}

The study protocol was approved by the Committee on Animal Research at Sabzevar University of Medical Sciences (document number:

IR.MEDSAB.REC.1397.047).

\section{Consent for publication}

No applicable.

\section{Competing interests}

There was no competing financial interests exist in this project.

\section{Author details}

'Student Research Center, Sabzevar University of Medical Sciences, Sabzevar, Iran. ${ }^{2}$ Cellular and Molecular Research Center, Department of Physiology and Pharmacology, Faculty of Medicine, Sabzevar University of Medical Sciences, Sabzevar, Iran. ${ }^{3}$ Cellular and Molecular Research Center, Sabzevar University of Medical Sciences, Sabzevar, Iran. ${ }^{4}$ Department of Physiology and Pharmacology, Faculty of Medicine, Sabzevar University of Medical Sciences, Sabzevar, Iran

\section{Received: 7 June 2021 Accepted: 22 November 2021}

\section{Published online: 29 November 2021}

\section{References}

1. Jemal A, Bray F, Center MM, Ferlay J, Ward E, et al. Global cancer statistics. CA Cancer J Clin. 2011:61(2):69-90.

2. Agrawal S. Late effects of cancer treatment in breast cancer survivors. South Asian J Cancer. 2014;3(2):112

3. Meshkani SE, Kooshan N, Moghadam AB, Falanji F, Adli A, Baghbani-Arani F, et al. Signaling roadmap to epithelial-mesenchymal transition in pterygium TWIST1 centralized. J Cell Physiol. 2019:234(10):18146-55.

4. Yin S-Y, Wei W-C, Jian F-Y, Yang N-S. Therapeutic applications of herbal medicines for cancer patients. Evidence-Based Complement Alternat Med. 2013;2013:302426

5. Liao G-S, Apaya MK, Shyur L-F. Herbal medicine and acupuncture for breast cancer palliative care and adjuvant therapy. Evidence-Based Complement Alternat Med. 2013;2013:437948.

6. Shareef M, Ashraf MA, Sarfraz M. Natural cures for breast cancer treatment: Elsevier; 2016;24(3):233-40.

7. Gu C, Yang X, Huang L. Cistanches herba: A neuropharmacology review. Front Pharmacol. 2016;7:289.

8. Amin B, Poureshagh $E$, Hosseinzadeh $H$. The effect of verbascoside in neuropathic pain induced by chronic constriction injury in rats. Phytother Res. 2016:30(1):128-35.

9. Zhou L, Feng $Y$, Jin $Y$, Liu $X$, Sui $H$, Chai $N$, et al. Verbascoside promotes apoptosis by regulating HIPK2-p53 signaling in human colorectal cancer. BMC Cancer. 2014;14(1):747.
10. Feng $Y$, Zhou L, Sun X, Li Q. Homeodomain-interacting protein kinase 2 (HIPK2): a promising target for anti-cancer therapies. Oncotarget. 2017;8(12): 20452.

11. Li J, Yang F, Wei F, Ren X. The role of toll-like receptor 4 in tumor microenvironment. Oncotarget. 2017;8(39):66656.

12. Awasthi S. Toll-like receptor-4 modulation for cancer immunotherapy. Front Immun. 2014;5:328.

13. Shetab Boushehri MA, Lamprecht A. TLR4-based immunotherapeutics in cancer: a review of the achievements and shortcomings. Molecular pharmaceutics. 2018;15(11):4777-800.

14. Ahmed A, Redmond HP, Wang JH. Links between Toll-like receptor 4 and breast cancer. Oncoimmunology. 2013;2(2):e22945.

15. Clark A, MacKenzie SH. Targeting cell death in tumors by activating caspases. Curr Cancer Drug Targets. 2008:8(2):98-109.

16. Yang B, Johnson TS, Thomas GL, Watson PF, Wagner B, Furness PN, et al. A shift in the $\mathrm{Bax} / \mathrm{BCl}-2$ balance may activate caspase-3 and modulate apoptosis in experimental glomerulonephritis. Kidney Int. 2002;62(4): 1301-13.

17. Wang Q, Zhang L, Yuan X, Ou Y, Zhu X, Cheng Z, et al. The relationship between the $\mathrm{BCl}-2 / \mathrm{Bax}$ proteins and the mitochondria-mediated apoptosis pathway in the differentiation of adipose-derived stromal cells into neurons. PloS ONE. 2016;11(10):e0163327.

18. Khodapasand E, Jafarzadeh N, Farrokhi F, Kamalidehghan B, Houshmand M. Is Bax/Bcl-2 ratio considered as a prognostic marker with age and tumor location in colorectal cancer? Iranian Biomed J. 2015;19(2):69.

19. Kwist K, Bridges W, Burg K. The effect of cell passage number on osteogenic and adipogenic characteristics of D1 cells. Cytotechnology. 2016;68(4): $1661-7$

20. Volpe DA, Hamed SS, Zhang LK. Use of different parameters and equations for calculation of IC 50 values in efflux assays: potential sources of variability in IC 50 determination. The AAPS J. 2014;16(1):172-80.

21. Livak KJ, Schmittgen TD. Analysis of relative gene expression data using real-time quantitative PCR and the $2-\Delta \Delta C T$ method. Methods. 2001;25(4): 402-8.

22. Rieger AM, Nelson KL, Konowalchuk JD, Barreda DR. Modified annexin V/ propidium iodide apoptosis assay for accurate assessment of cell death. JoVE (J Visualized Exp). 2011, e2597;50.

23. Carrillo-Ocampo D, Bazaldúa-Gómez S, Bonilla-Barbosa J, Aburto-Amar R, Rodríguez-López V. Anti-inflammatory activity of iridoids and verbascoside isolated from Castilleja tenuiflora. Molecules. 2013;18(10):12109-18.

24. Zhang Y, Liu B, Wu H, Li B, Xu J, Duan L, et al. Anti-tumor activity of verbascoside loaded gold nanoparticles. J Biomed Nanotechnol. 2014; 10(12):3638-46.

25. Jia W-Q, Wang Z-T, Zou M-M, Lin J-H, Li Y-H, Zhang L, et al. Verbascoside inhibits glioblastoma cell proliferation, migration and invasion while promoting apoptosis through upregulation of protein tyrosine phosphatase SHP-1 and inhibition of STAT3 phosphorylation. Cell Physiol Biochem. 2018; 47(5):1871-82

26. Seyfi D, Behzad SB, Nabiuni M, Parivar K, Tahmaseb M, Amini E. Verbascoside Attenuates Rac-1 and HIF-1a Signaling Cascade in Colorectal Cancer Cells. Anti Cancer Agents Med Chem (Formerly Current Medicinal Chemistry-Anti-Cancer Agents). 2018;18(15):2149-55.

27. Zhang $Y, Y$, Yan $Y$, Wu H, Xie $Z$, Wu $Y$, Song $X$, et al. Effect of verbascoside on apoptosis and metastasis in human oral squamous cell carcinoma. Int J Cancer. 2018;143(4):980-91.

28. Campbell KJ, Tait SW. Targeting BCL-2 regulated apoptosis in cancer. Open biology. 2018;8(5):180002.

29. Warren CF, Wong-Brown MW, Bowden NA. BCL-2 family isoforms in apoptosis and cancer. Cell death \& disease. 2019;10(3):177.

30. Elmore S. Apoptosis: a review of programmed cell death. Toxicol Pathol. 2007:35(4):495-516.

31. Segawa K, Nagata S. An apoptotic 'eat me'signal: phosphatidylserine exposure. Trends Cell Biol. 2015;25(11):639-50

32. Wlodkowic D, Skommer J, Darzynkiewicz Z. Flow cytometry-based apoptosis detection. Apoptosis: Springer; 2009. p. 19-32

33. Harberts E, Fishelevich R, Liu J, Atamas SP, Gaspari AA. MyD88 mediates the decision to die by apoptosis or necroptosis after UV irradiation. Innate Immun. 2014;20(5):529-39.

34. Aliprantis AO, Yang RB, Weiss DS, Godowski P, Zychlinsky A. The apoptotic signaling pathway activated by Toll-like receptor-2. EMBO J. 2000;19(13): 3325-36. 
35. Laird MH, Rhee SH, Perkins DJ, Medvedev AE, Piao W, Fenton MJ, et al. TLR4/MyD88/PI3K interactions regulate TLR4 signaling. J leukoc Biol. 2009; 85(6):966-77.

36. Pesce M, Franceschelli S, Ferrone A, De Lutiis MA, Patruno A, Grilli A, et al. Verbascoside down-regulates some pro-inflammatory signal transduction pathways by increasing the activity of tyrosine phosphatase SHP-1 in the U937 cell line. J Cell Mol Med. 2015;19(7):1548-56.

37. Hayden MS, Ghosh S. Signaling to NF-KB. Genes \& Dev. 2004;18(18):2195-224.

38. Janssens S, Beyaert R. A universal role for MyD88 in TLR/L-1R-mediated signaling. Trends Biochem Sci. 2002;27(9):474-82.

\section{Publisher's Note}

Springer Nature remains neutral with regard to jurisdictional claims in published maps and institutional affiliations.

Ready to submit your research? Choose BMC and benefit from:

- fast, convenient online submission

- thorough peer review by experienced researchers in your field

- rapid publication on acceptance

- support for research data, including large and complex data types

- gold Open Access which fosters wider collaboration and increased citations

- maximum visibility for your research: over $100 \mathrm{M}$ website views per year

At BMC, research is always in progress.

Learn more biomedcentral.com/submissions 